\title{
Upaya Tiongkok untuk Menghidupkan Kembali Jalur Sutra dalam Perspektif Balance of Power
}

\author{
M. Musa Al Hasyim \\ Pascasarjana Kajian Timur Tengah dan Islam Universitas Indonesia \\ m.musa@ui.ac.id
}

\section{Abstrack}

China has regenerated the ancient Silk Road through the BRI (Belt and Road Initiative) scheme throughout the Middle East. The Chinese presence in the region has as well as the new hegemony, slowly shifting the position of the United States and its allies in the Middle East. The escalation of the conflict between Iran and Saudi Arabia does not make China supporting or denying both of them because China keeps the concept of non-intervention in the BRI scheme. The purpose of this study is to analyze the future of the Silk Road BRI by China in the Middle East by using the Balance of Power perspective, especially the Regional Security Complex overview. By conducting an in-depth literature study, the author finds that China is neither eternal friend nor a constant enemy of any Middle East countries. China relation with the countries of the region depends on the future situation. China can have good relations with Iran, Saudi Arabia, Israel, and Palestine at the same time. However, the relationship can change if the United States and some Middle East countries are making new alignment to obstruct China's hegemony.

Kata Kunci: Balance of Power, Belt and Road Initiative, Middle East, Regional Security Complex, Silk Road

\section{Abstrak}

Tiongkok telah membangkitkan kembali Jalur Sutra Klasik melalui skema BRI (Belt and Road Initiative), termasuk Jalur Sutra di sepanjang Timur Tengah. Kemunculan Tiongkok di kawasan itu menjadikannya sebagai hegemoni baru, menggeser perlahan-lahan posisi Amerika Serikat dan sekutunya di sana. Eskalasi konflik 
antara Iran dan Arab Saudi tidak membuat Tiongkok membela atau membelot dari keduanya, karena Tingkok mengusung konsep non-intervensi dalam skema BRI tersebut. Tujuan penelitian ini adalah menganalisis masa depan skema BRI di Timur Tengah dengan menggunakan perspektif Balance of Power, termasuk konsep turunannya, Regional Security Complex (RSCs). Melalui studi kepustakaan yang mendalam, penulis menemukan bahwa Tiongkok bukanlah kawan abadi, bukan pula lawan abadi bagi negara-negara Timur Tengah. Tiongkok bisa menjadi keduanya dan bisa pula tidak keduanya, tergantung situasi di masa depan. Tiongkok dapat menjalin hubungan baik dengan Iran, Arab Saudi, Israel, atau Palestina. Namun hubungan ini dapat berubah manakala Amerika Serikat dan sejumlah negara di Timur Tengah membentuk aliansi baru untuk menghambat hegemoni Tiongkok.

Kata Kunci: Balance of Power, Jalur Sutra, Regional Security Complex, Skema BRI Tiongkok, Timur Tengah

\section{Pendahuluan}

Timur Tengah merupakan kawasan yang memiliki kekayaan minyak dan gas melimpah. Hampir sebagian besar negara-negara modern di Timur Tengah juga pengekspor minyak dan gas seperti: Aljazair, negara-negara Teluk (Kuwait, Bahrain, Irak, Oman, Qatar, Arab Saudi, dan Uni Emirat Arab), Iran, Libya, Mesir, Sudan, Suriah, Tunisia, dan Yaman. Jantung perekonomian dalam negeri di sana sangat bergantung pada dua komoditas tersebut. Roda-roda pendidikan, sosial dan budaya tak bisa lepas dari hasil eksplorasi minyak dan gas (Sihbudi, 2007: 419-430).

Kehadiran minyak di Timur Tengah memicu berbagai konflik. Banyak yang menduga bahwa kawasan itu berkonflik dan melakukan perang antarnegara karena cadangan minyak yang melimpah sampai muncul anekdot bahwa selama ada minyak, perang tidak akan berhenti di Timur Tengah (Tobing, 2020). Praduga ini lalu memunculkan satir bahwa Timur Tengah terkena kutukan sumber daya minyak.

Harga minyak kerap kali naik dan turun seiring dengan munculnya berbagai konflik yang tak berkesudahan. Krisis Suez (1956), Krisis Minyak 1973, Revolusi Islam Iran 1970-1980, Perang Irak-Iran 1980-1988, Perang Teluk 1990-1991, Krisis Ekonomi Asia 1997, Perang Irak 2003-2011, Arab Spring 2010-2012, dan hebohnya ISIS yang menaikkan tensi perang atau konflik di sana (Tobing, 2020). 
Eksplorasi minyak ini mengundang beberapa negara untuk datang ke Timur Tengah. Beberapa negara seperti Rusia, Tiongkok, Amerika Serikat (AS), dan negaranegara di Eropa, memiliki power dan pengaruh yang kuat di sana. Ini karena Timur Tengah mengandalkan peralatan modern dari mereka. Minyak juga telah mengubah iklim politik dalam negeri. Minyak mengubah negara-negara yang tadinya kaya sekali lantas menjadi miskin sekali hanya karena bergantung pada penjualan minyak yang tak dapat diperbaharui (Long \& Reich, 2002: 1-6).

Kondisi semacam ini membuat Timur Tengah mulai memodernisasi segala aspek kehidupan. Mereka perlahan-lahan mengurangi kebergantungan pada minyak, karena minyak bukanlah energi terbarukan seperti pohon yang dapat diperbanyak atau diperbaharui. Harga minyak yang turun pada tahun 2014 kemudian naik drastis pada tahun 2018 membuktikan bahwa minyak tidak semelimpah dulu dan mengindikasikan bahwa era rezim minyak sebentar lagi akan berakhir (Suwaidi, 2018: 77). Fakta ini diperkuat dengan banyaknya temuan yang membuktikan bahwa minyak akan segera habis kurang dari 100 tahun lagi (Onsman, 2011: 519).

Salah satu upaya modernisasi di Timur Tengah adalah menghidupkan kembali Jalur Sutra Kuno yang sudah digunakan jauh sebelum Islam datang. Jalur Sutra memainkan peran penting dalam kehidupan kuno Timur Tengah, karena perdagangan merupakan mata pencaharian dan pemasukan utama di era sebelum minyak ditemukan. Jalur Sutra ini memudahkan (Murad, 2007: 77-79). Setelah minyak mulai habis, saatnya ekonomi kreatif, pariwisata, pendidikan, transfer teknologi dan perdagangan memainkan peran dalam membangun peradaban baru di Timur Tengah. Di sinilah Jalur Sutra dibutuhkan untuk memudahkan mobilisasi sendi-sendi kehidupan dan perekonomian di Timur Tengah.

Jalur Sutra diperkenalkan kembali oleh Tiongkok sebagai salah satu rival terbesar AS pada tahun 2013 di beberapa negara Timur Tengah. Jika dulu Barat mempopulerkan eksplorasi minyak, kini Asia Timur mencoba mempopulerkan Jalur Sutra (Sarwar, 2017: 15). Sebuah pertanyaan besar muncul, akankah kehadiran Tiongkok melalui skema the Belt and Road Initiative (BRI) mampu mengurangi hegemoni dan dominasi Barat, terutama AS, di kawasan Timur Tengah?

Beberapa penelitian sebelumnya banyak membahas kehadiran Tiongkok di Timur Tengah. Alexander Neill (2014) menjelaskan bahwa Tiongkok mulai mesra dengan Timur Tengah. Sejumlah investasi besar-besaran disuntikkan ke kawasan. Baik Tiongkok atau Timur Tengah masing-masing memiliki kepentingan, mulai dari ideologi, militer, dan ekonomi.Tidak seperti Barat, Tiongkok lebih menekankan prinsip 
non intervensi dan murni insentif ekonomi. John Calabrese (2018) menyimpulkan bahwa BRI di Timur Tengah ini tidak semulus yang diharapkan bila ditinjau dari kondisi politik dalam negeri. Di Iran, misalnya, masih banyak yang berpikir bahwa Tiongkok menggunakan prinsip zero-sum, karena keuntungan terbesar diraih oleh Tiongkok.

Sementara itu, dalam penelitian ini, penulis menggunakan perspektif Balance of Power dalam mengkaji kehadiran Tiongkok melalui BRI di Timur Tengah. Penelitian ini diharapkan dapat memperkaya kajian terbaru soal kehadiran Tiongkok di wilayah itu dan menjadi bahan perbandingan bagi penelitian yang akan datang, mengingat keadaan dunia yang tidak pasti setiap tahunnya. Uraian selanjutnya akan memaparkan penjelasan singkat mengenai konsep Balance of Power, kemudian berlanjut ke pembahasan inti seperti: sejarah singkat hegemoni di Timur Tengah, Jalur Sutra Klasik, Jalur Sutra Modern, kehadiran Tiongkok di Timur Tengah melalui skema BRI, Balancing Power Iran-Arab Saudi dengan skema BRI dan berakhir dengan kesimpulan.

\section{Perspektif Balance of Power dan Regional Security Complex}

Secara umum, masih belum ada kesepakatan di kalangan akademisi dalam mengartikan konsep ini. Fenelon mengartikannya sebagai tindakan nyata oleh sebuah negara agar tetangganya tidak menjadi negara kuat, karena jika negara tetangga kuat, akan akan tercipta perubahan sistem yang ada di sekitarnya. Dari sinilah dibutuhkan sebuah keseimbangan dan keselarasan agar tidak ada negara yang terlalu kuat. Sementara Morgenthau mendefinisikan Balance of Power sebagai keseimbangan yang mengacu kepada distribusi power di antara beberapa negara sehingga mereka memiliki hampir kesamaan power (Sheehan, 2000: 2-3).

BalanceofPowermerupakanturunandariteoriHubungan Internasionaltradisional yang berkaitan dengan Realisme, di mana faktor power sangat menentukan dalam sebuah hubungan dengan negara lain dengan empat prinsip dasar. Pertama, negara berdaulat adalah kunci utama dalam sebuah sistem internasional. Kedua, kebijakan luar negeri dipengaruhi oleh kondisi politik dalam negeri atau wilayah domestik. Ketiga, politik internasional adalah sebuah perjuangan untuk mendapatkan power dalam lingkungan internasional yang anarki. Keempat, setiap negara memiliki kemampuan yang berbeda untuk meraih tujuan dan mempertahankan kepentingannya (Sheehan, 2000: 4-5). 
Logika Balance of Power sangat penting untuk memahami politik internasional, termasuk dalam memahami kondisi politik regional. Balance of Power skala regional dan umum atau internasional memanglah berbeda, namun umumnya Balance of Power skala internasional selalu menjadi perhatian bersama. Mearsheimer beranggapan bahwa tidak ada Balance of Power skala internasional kecuali ada sebuah hubungan keseimbangan di tingkat regional (Little, 2007: 213-216).

Dasar pendekatan untuk mendapatkan power ini berangkat dari sejarah. Masa lalu menentukan apa yang terjadi saat ini (Sheehan, 2000: 9) Sejarah menuliskan bahwa setelah Perang Dingin berakhir, timbul anggapan bahwa kondisi dunia berubah menjadi unipolar dimana AS adalah hegemoni satu-satunya di dunia setelah Uni Soviet tumbang. Pendapat ini sebenarnya masih menjadi perdebatan di kalangan akademisi. Mearsheimer berpendapat AS bukanlah hegemoni global, melainkan hegemoni regional, karena sistem internasional yang rumit dimana setiap regional belum seimbang power-nya di masing-masing negara (Little, 2007: 216).

Kemudian tesis yang menganggap AS sebagai hegemoni global mengacu kepada penguasaan nuklir yang dimulai sejak AS meledakkan bom nuklir pertama kali di Jepang pada 1945. Nuklir menjadi momok menakutkan bagi kawasan. Dari sini, negara saling membentuk aliansi untuk membendung hegemoni global terkait penggunaan nuklir. Baik NATO atau Pakta Warsawa memiliki bloknya masingmasing. Nuklir yang menjadi ancaman global itu membuat tak sembarang negara diperbolehkan merakitnya. AS sebagai dominasi nuklir selanjutnya dianggap sebagai hegemoni global (Sheehan, 2000: 172-183).

Selama Perang Dingin, AS bersekutu dengan Eropa Barat dan, dengan paham kapitalisme, menjadikan mereka sebuah kekuatan besar yang berhadapan dengan kubu Uni Soviet yang mengusung paham komunisme. Setelah abad 19 berlalu, dinamika global berubah. Eropa bukan lagi pusat perkembangan teknologi dan beragam fitur lainnya. Persebaran kompetensi dalam memproduksi inovasi teknologi semakin merata. Wilayah Timur yang dianggap kalah dalam Perang Dingin mulai bangkit lagi membangun basis teknologi dan ekonomi mereka. Militer dan nuklir bukan lagi patokan utama dalam Balance of Power (Yang, 2013: 43-44).

Di era pasca Perang Dingin, ekonomi semakin menjadi faktor penentu dari konsep Balance of Power. Tanpa ekonomi yang memadai, sebuah negara mustahil membangun pangkalan militer atau mengembangkan senjata nuklirnya. Aliansi tidak hanya sebatas militer; dunia saat ini juga saling membentuk aliansi atas ekonomi. Negara yang ekonominya kuat berkemungkinan menjadi hegemoni 
global. Mereka tidak takut berhadapan dengan superioritas AS (R. Brawley, 2004: 77-98). Di atas garis perubahan dunia, tidak selamanya AS merajai ekonomi global. Kemunculan Tiongkok sebagai raksasa global perlahan-lahan menggeser posisi AS sebagai hegemoni global. Bagaimanapun juga militer selalu mengikuti ekonomi dalam negerinya.

Sementara itu, Regional Security Complex (RSCs) akan memetakan apa sebenarnya yang terjadi di Timur Tengah setelah Tiongkok datang dengan proyek besarnya. Sejarah RSCs ini dibagi menjadi tiga tahapan: pertama, era modern dari tahun 1500 sampai 1945. Kedua, masa Perang Dingin dan Dekolonialisasi dari 1945 sampai1989. Ketiga, era pasca Perang Dingin sejak 1990 (B. Buzan, 2003: 14).

Semua tahapan di atas menjelaskan bahwa dunia dipegang dan dikendalikan oleh negara, apalagi setelah sistem teritori negara semakin jelas. Masing-masing negara memetakan mana saja wilayah yang menjadi kekuasaannya dan mana yang bukan. Negara berperan penting dalam membentuk sistem internasional. Kunci keamanan dari sistem ini tergantung pada tetangga negara. Semakin kuat tetangga, semakin mengkhawatirkan situasi negara lain. Alhasil, negara saling membentuk aliansi untuk menggambarkan mana teman dan mana pula musuh (B. Buzan, 2003: 15).

\section{Sejarah Singkat Hegemoni di Timur Tengah}

Di era Perang Dingin, sistem dunia adalah bipolar dimana kekuatan terbesar berasal dari Uni Soviet dan AS. Setelah Uni Soviet akhirnya terpecah menjadi beberapa negara kecil, muncullah era baru bagi AS untuk memimpin dunia. AS kemudian dianggap sebagai polisi dunia karena memenangi Perang Dingin yang kemudian meruntuhkan Uni Soviet. Dari sini pula konsep hegemoni mulai banyak diminati. Konsep hegemoni selalu bersanding dengan Balance of Power. Tanpa Balance of Power, hegemoni sebuah negara akan memberikan ancaman bagi kawasan.

Sejarah mencatat bahwa AS bukanlah negara pertama yang mendapat predikat negara superior. AS juga bukan satu-satunya hegemoni dalam sejarah. Ini membuktikan bahwa hegemoni sebuah negara tidak bersifat kekal, selalu berubah dan berganti mengikuti proses perubahan yang ada. Setidaknya, ada delapan sejarah hegemoni yang luput dari perhatian bersama, yaitu sebagai berikut.

Pertama, hegemoni Assyria berlangsung dalam kurun waktu yang cukup lama, bermula dari 900-600 SM. Kekaisan Assyria mencakup wilayah kekuasaan dari Persia 
sampai Jerusalem. Kerajaan ini dikelilingi oleh beberapa kerajaan besar lainnya seperti: Kerajaan Urartu, Babilonia dan Elam. Di samping itu, kerajaan-kerajaan kecil juga turut berperan dalam menyeimbangkan hegemoni Assyria. Kekaisaran ini menjadi hegemoni karena rajanya dianggap sebagai penguasa seluruh umat manusia di dunia. Hegemoni ini tercoreng dengan tabiat buruk kekaisaran yang kejam terhadap lawan atau musuh yang berhasil dikalahkan (Kaufman \& Wohlforth, 2007: 23-27).

Kedua, superioritas Persia dan, ketiga, Romawi. Kedua imperium ini masingmasing menguasai dunia abad 5 sebelum Masehi dan kurun waktu 201-200 SM. Persia menggeser posisi Assyria di mana kekuatannya mendominasi kawasan Timur Tengah dan Asia Kecil (Little, 2007: 52). Romawi menjadi hegemoni karena wilayah dan populasinya yang sangat besar. Ini tidak lepas dari pengaruh konsep negara-kota kuno yang dianut olehnya. Di samping itu, Romawi memiliki militer yang cukup kuat dengan anggaran yang besar. Kesolidan populasinya disebabkan oleh kepercayaan mereka pada dewa-dewi yang menyatukan mereka dalam setiap upacara seremonial keagamaan (Eckstein, 2007: 73).

Keempat, hegemoni India Kuno berlangsung selama 600-232 SM. Konfederasi Vajjian telah lama menentang dominasi yang dilakukan oleh Magadhan, bukan dengan pertempuran, melainkan dengan strategi. India modern itu sudah terbagibagi menjadi banyak kerajaan, namun Kerajaan Mauryan mengambil alih hegeomi dengan cara strategi tersebut. Hanya saja, strategi ini dilakukan sembunyi-sembunyi melalui hutan belantara di India pada masa itu (Brenner, 2007: 199-120).

Kelima, Tiongkok juga pernah mendominasi peta kekuasaan dunia. Adalah Dinasti Qin dengan kecerdasan strategi militer telah membuatnya ditakuti negerinegeri tetangga. Kondisi geografis Tiongkok juga mendukung fakta ini, dimana Tiongkok Kuno dikelilingi sungai besar, bukit, gurun, dan gunung. Tak sebatas itu, Dinasti Qin juga cakap dalam urusan ekonomi dan administrasi. Akibatnya, aliansi anti-Qin sulit mengalahkannya. Kondisi ini membuat Dinasti Qin menjadi hegemoni sekaligus ancaman bersama karena kekuatannya, apalagi mereka ini berhasil menyatukan Tiongkok daratan sehingga bangsa luar sulit menembus benteng pertahanan mereka (Hui, 2007: 146).

Keenam, Timur Tengah lagi-lagi menguasai dominasi dunia setelah sebelumnya Persia. Adalah Turki Utsmani yang kekuasaannya hampir mencakup seluruh wilayah Arab, Afrika Utara sampai Eropa Timur (Levinson, 1994: 374). Kekuasaan Turki Utsmani ini mulai bersinar pada tahun 1451-1453. Pada kurun itu, Mehmet II atau 
Fatih Sang Penakluk memukul mundur Konstantinopel (Freely, 2019: 156). Hegemoni Turki Utsmani perlahan memudar sejak Barat menjajah beberapa wilayah di dunia, termasuk Timur Tengah, di samping tentu saja pengaruh faktor internal. Kendati Belanda, Portugis dan Inggris muncul sebagai kekuatan baru, namun belum muncul satu superioritas pada masa itu karena kekuatan ketiga negara itu cukup berimbang (Hanifah, 2017: 106).

Ketujuh, seperti sudah dibahas pada uraian sebelumnya, AS masih dianggap sebagai hegemoni dunia saat ini setelah Uni Soviet hancur pasca-Perang Dingin. Fakta ini didukung dengan kepemilikan senjata nuklir AS yang tiada tandingan. Menurut data dari Global Fire Power, kekuatan militer AS masih menduduki peringkat satu, disusul Rusia dan Tiongkok. Kekuatan militer ini didukung dengan adanya pangkalan militer AS yang tersebar di berbagai belahan dunia. AS juga terlibat dalam penyeimbangan kekuatan paling dominan, karena negara manapun yang memiliki senjata nuklir, kimia, maupun biologi akan berhadapan dengan AS dan sekutunya. Artinya, tidak boleh ada negara yang lebih kuat dari AS (T.V. Paul, 2004: 7-9).

Kedelapan prediksi Tiongkok sebagai kekuatan hegemoni baru menggantikan AS sudah lama menjadi perbincangan di kalangan akademisi. Tiongkok ini cukup unik, karena sistem politik negaranya menganut komunisme, tapi sistem ekonominya sangat liberal. Kekuatan Tiongkok sebagai hegemon baru ini didukung oleh berbagai faktor, namun yang paling mencolok adalah kekuatan ekonominya yang begitu perkasa. Selama berabad-abad, hegemoni sebuah negara tidak dihitung lagi berdasarkan kekuatan militernya, tetapi juga stabililitas keuangan negara dan kuasa perdagangannya di seluruh penjuru dunia (Yang, 2013: 41-42).

Tiongkok sebagai kekuatan baru dunia masih menjadi perdebatan, karena di Asia Timur setidaknya masih ada Jepang dan Korea Selatan yang cukup bersinar. Tetapi, jika konteksnya adalah Timur Tengah, bisa jadi Tiongkok disebut sebagai kekuatan baru. Hal ini didukung oleh langkah negri Tirai Bambu itu dalam menggelontorkan investasi besar-besaran untuk membangun kembali Jalur Sutra di sepanjang wilayah Timur Tengah. Jalur Sutra merupakan sebuah kebanggaan bagi Tiongkok, karena ia menjadi saksi bahwa Tiongkok sudah jaya sejak zaman dulu. Tetapi, apa Jalur Sutra ini dimiliki oleh Tiongkok sendiri? Atau itu milik bersama, namun Tiongkok yang paling banyak diuntungkan? Pertanyaan ini akan dibahas dalam uraian selanjutnya.

\section{Jalur Sutra Klasik}

Jalur Sutra kuno, jika merujuk pada pendapat ahli geografi berkebangsaan Jerman, Ferdinand Von Richthofen, merupakan rute yang menghubungkan darat 
dan laut melalui Timur Jauh, Asia Tengah, wilayah India, dataran tinggi Anatolia, Kaukasia, Semenanjung Arab, Laut Tengah dan Eropa. Definisi ini juga dipakai oleh UNESCO sebagai jalur perdagangan kuno yang bernilai sejarah. Jalur ini menjadi tempat penting bertukarnya ide, ideologi, agama dan kepercayaan, budaya, bahasa, tradisi, serta ekonomi. Namun belum ada kesepakatan, titik mulai dan titik terpenting dari Jalur Sutra ini persisnya di mana (Sarwar, 2017: 14-15).

Di masa Nabi Muhammad, bentang-bentang rute perdagangan di Jalur Sutra ini sudah tampak. Sebagian bangsa Quraish Mekkah yang berprofesi pedagang melakukan perjalanan bisnis ke utara, barat dan selatan sesuai kondisi cuaca. Jika musim dingin tiba, mereka berdagang ke selatan, yakni Yaman atau Ethiopia, karena cuaca di selatan cenderung hangat. Jika musim panas tiba, bangsa Quraish berbisnis ke utara, yakni Syria, Yordania, Palestina, dan Lebanon, karena cuaca di daerahdaerah itu lebih dingin. Kadang juga mereka melakukan perjalanan ke barat seperti: ke Turki dan Eropa Barat. Nabi Muhammad sendiri pernah melakukan perjalanan bisnis bersama pamannya di usia 12 tahun untuk berdagang ke Syam dengan jarak 1.500 kilometer, atau setara dengan 3 negara saat ini (Ulum, 2015: 40-41).

Rudnyckyj berpendapat bahwa Jalur Sutra semakin terkoneksi semenjak Nabi Muhammad SAW berhijrah ke Madinah, berbarengan dengan penyebaran dakwahnya bersama sahabatnya. Ketika banyak pedagang memeluk Islam, mereka turut menyampaikan pesan keesaan Allah dengan cara berdagang hingga ke Asia. Beberapa di antaranya dibuktikan dengan adanya jejak kabilah-kabilah dagang Arab di Tiongkok. Bahkan ada yang berpendapat kabilah-kabilah itu telah menjangkau Nusantara (Ho, 2013: 144-145). Setelah itu, estafet kepemimpinan Nabi Muhammad dilanjutkan oleh khulafa al-rasyidin, Dinasti Umayyah, Dinasti Abbasiyah sampai Turki Utsmani. Selama itu pula Jalur Sutra kian populer, terutama di Abad Keemasan Dinasti Abbasiyah.

Pada masa Dinasti Abbasiyah, Baghdad menjadi pusat perdagangan tersibuk dan terbesar di dunia. Itu semua bermula ketika pusat pemerintahan dipindahkan dari Damaskus ke Baghdad. Beberapa industri bermunculan untuk memenuhi kebutuhan masyarakat, mulai dari sabun, sutra, keramik, kapal, senjata dan lainnya, namun perdagangan dipusatkan di Baghdad. Di sana ada 100 kincir angin, 4000 pabrik gelas dan 30.000 kilang keramik. Di kota Seribu Satu Malam itu pula macammacam hasil produksi, pertanian, dan perkebunan sangat berkembang pesat yang kemudian dijual kembali oleh beberapa kapal-kapal pedagang dari seluruh dunia, termasuk ke Tiongkok (Farah, 2014: 37-45). 
Timur Tengah sebagai wilayah sentral mendapatkan posisi strategis dalam peta perdagangan dunia. Tukar-menukar barang dan kebutuhan antarnegara tidak bisa dilepaskan dari jalur ini. Jalur ini pula yang membuat budaya konsumsi semakin meningkat, karena adanya banyak pilihan produk yang ditawarkan. Misalnya, Tiongkok mendapatkan karpet permadani indah dari Baghdad, sementara Baghdad mendapatkan kain sutra bagus dari Tiongkok (Freely, 2019: 279-280).

\section{The Silk Road and Arab Sea Routes (8th - 14th Centuries)}

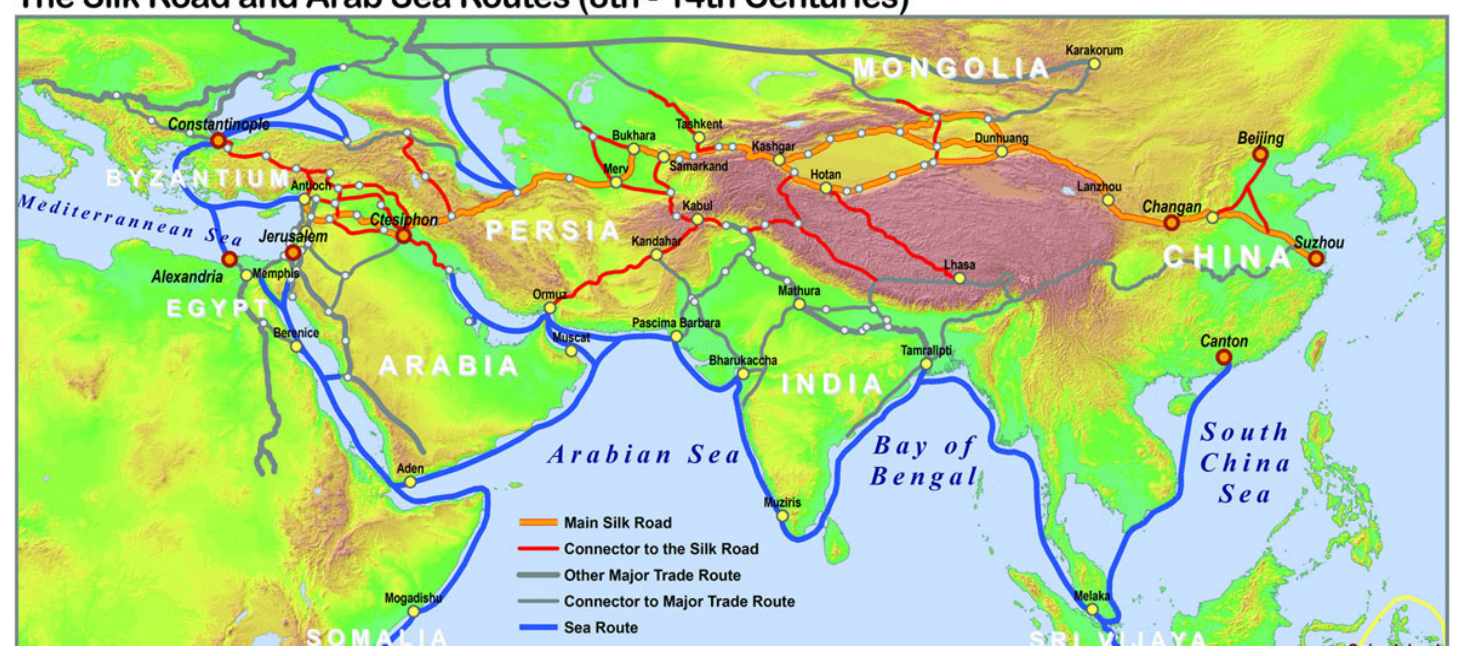

Rute Jalur Sutra dan Laut Arab abad ke- 8-14. (sumber: chinadiscovery.com, 2020)

Jalur Sutra dianggap tidak akan pernah ada jika tidak ada peran Tiongkok di dalamnya. Jalur ini dipopulerkan Tiongkok ketika mereka merajai perekonomian dunia berabad-abad silam. Kata 'sutra' yang disematkan pada jalur ini merujuk kepada benang sutra dan tekstil sutra yang merupakan komoditas ekspor Tiongkok ke berbagai belahan dunia. Permintaan sutra yang tinggi itu membuat Tiongkok semakin terbiasa dengan jalur ini. Tak hanya sutra, rempah-rempah dan dupa dari Tiongkok juga kerap dibutuhkan oleh negara-negara. Kenaikan populasi di dunia juga membuat Jalur Sutra semakin ramai (Liu, 2010: 109).

Jalur Sutra Klasik ini dibagi menjadi tiga jalur utama sebelum akhirnya terkoneksi sampai ke seluruh belahan dunia. Pertama, Buddhist Road yang menghubungkan Tiongkok ke India melalui Pamir dan beberapa oasis di Taklamakan sampai Gurun Gobin. Buddhist Road ini dikenal untuk menyebarkan ajaran Budha. Bersamaan Buddhist Road, para pedagang juga mulai menggunakan jalur ini. Kedua, Mongol Road yang dimulai pada abad 15, ditandai kekuasaan Mongol atas jalur ini. Jalur utama ini mulai mempertemukan para seniman, pedagang, cendekiawan, dan pasukan militer. Mongol Road ini akhirnya menghubungkan jalur dengan akses 
yang lebih mudah dan cepat setelah ada Mediterranean Road. Ketiga, Mediterranean Road ini yang menghubungkan dunia Islam, Kristen, dan Budha. Pertukaran budaya Barat dan Timur mulai terasa setelah Mediterranean Road dikenalkan. Pertukaran ini berjalan bersamaan dengan adanya Jalur Sutra Modern ketika bangsa Eropa mulai menjajah di berbagai wilayah dunia (Forêt \& Kaplony, 2008: 2-5)

\section{Jalur Sutra Modern}

Jalur Sutra modern ini dimulai sejakminyakkian dibutuhkan untukmenghidupkan industri-industri modern. Eksplorasi minyak di Timur Tengah dimulai pertama kali di Persia pada tahun 1908 oleh William Arcy, 51 \% sahamnya kemudian dikuasai Inggris (Partowidagdo, 2014). Eksplorasi minyak ini mengundang beberapa negara untuk datang ke Timur Tengah. Beberapa negara seperti: Rusia, Tiongkok, AS, dan negaranegara di Eropa, begitu mengandalkan minyak Timur Tengah, sementara kawasan ini sendiri membutuhkan tenaga ahli dan peralatan modern dari negara-negara besar tersebut. Minyak telah mengubah negara-negara yang tadinya kaya sekali lantas menjadi miskin sekali karena hanya bergantung pada minyak (Long \& Reich, 2002: 1-6).

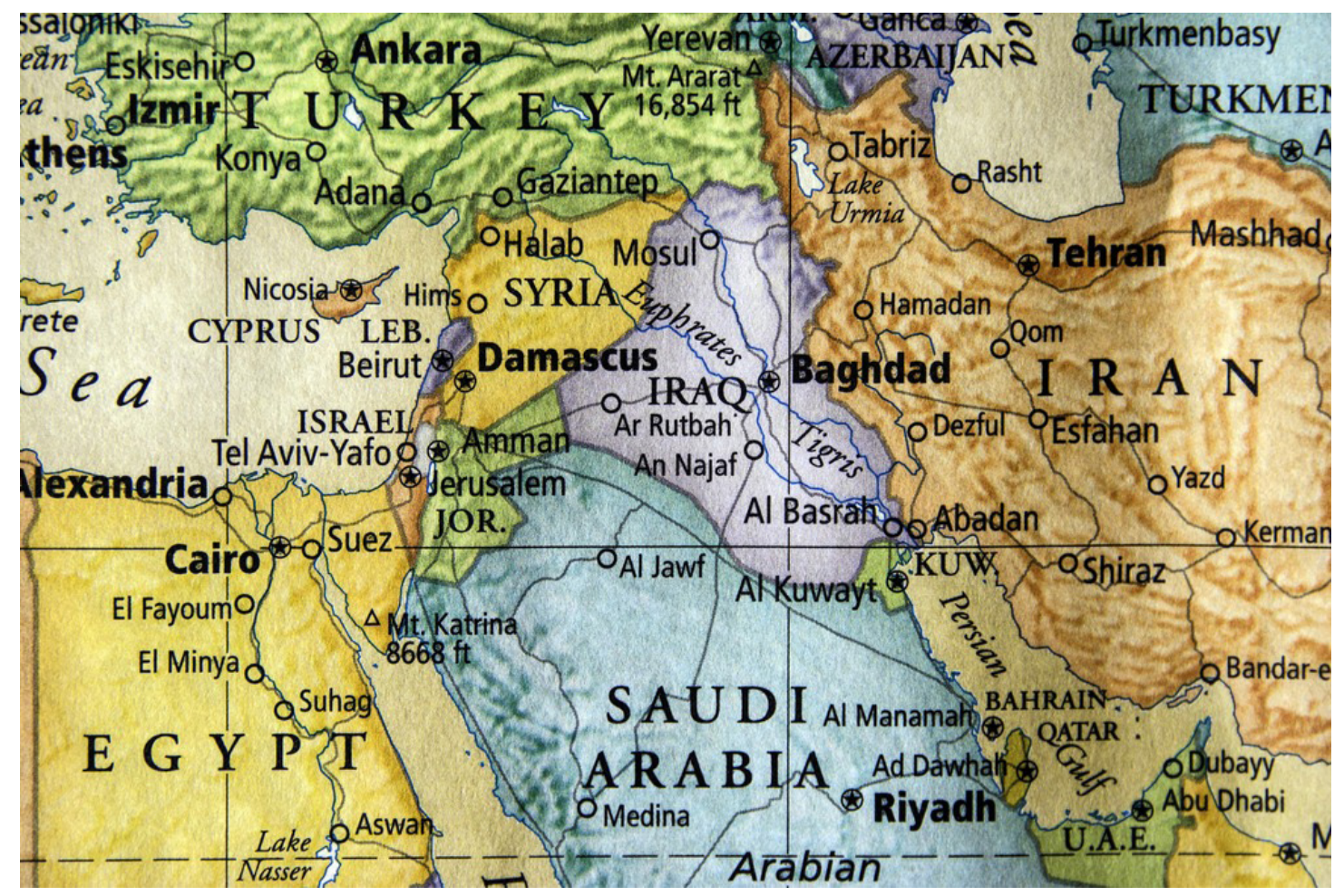

Kilang minyak dan Terusan Suez (sumber: vox.com, 2019) 
Denyut penting lain di Timur Tengah adalah Terusan Suez. Terusan ini dibangun oleh bangsa Eropa yang selesai dibangun pada tahun 1869 oleh Napoleon Bonaparte dari Perancis untuk bisa mengantarkan minyak-minyak mentah ke negara mereka dengan ongkos yang lebih hemat. Terusan Suez adalah jalur terpenting dalam bingkai Jalur Sutra. Terusan ini dapat menghubungkan Laut Merah dan Laut Tengah sehingga kapal-kapal ekspedisi tidak perlu memutar ke Tanjung Harapan di Afrika Selatan untuk mencapai Timur Tengah. Sebelum ada terusan ini, bangsa Eropa dan Barat harus memutar balik ke Afrika Selatan terlebih dahulu atau melalui Laut Tengah lalu disambung via darat kemudian kembali ke Laut Merah sehingga ongkos yang dikeluarkan sangat membengkak. Kilang-kilang minyak di seluruh Timur Tengah semakin mudah ditransfer ke negara-negara Barat berkat adanya Terusan Suez (Pratama, 2018). Posisi Barat menjadi lebih kuat di Timur Tengah, apalagi pada waktu itu Barat dan sekutu menjajah di berbagai wilayah di Timur Tengah.

Di akhir abad 20, Tiongkok tidak bisa menafikan diri dari transfer minyak Timur Tengah. Pada tahun 1993, Tiongkok mulai mengadopsi strategi going out untuk memenuhi kebutuhan energi dalam negerinya. Merujuk sebuah laporan yang diterbitkan Agustus 2010 silam, Tiongkok telah menjadi konsumen energi terbanyak di dunia melampaui AS. Fakta ini didukung oleh industrialisasi Tiongkok yang semakin besar. Banyaknya pembangunan infrastruktur dan industri berat membuat Tiongkok bergantung pada minyak mentah. Isu keamanan energi mulai diperbincangkan di Tiongkok sampai dibentuk komisi nasional energi yang dipimpin langsung oleh perdana menteri (Al-Rawashdeh \& Al-Qatatsheh, 2017: 39-40).

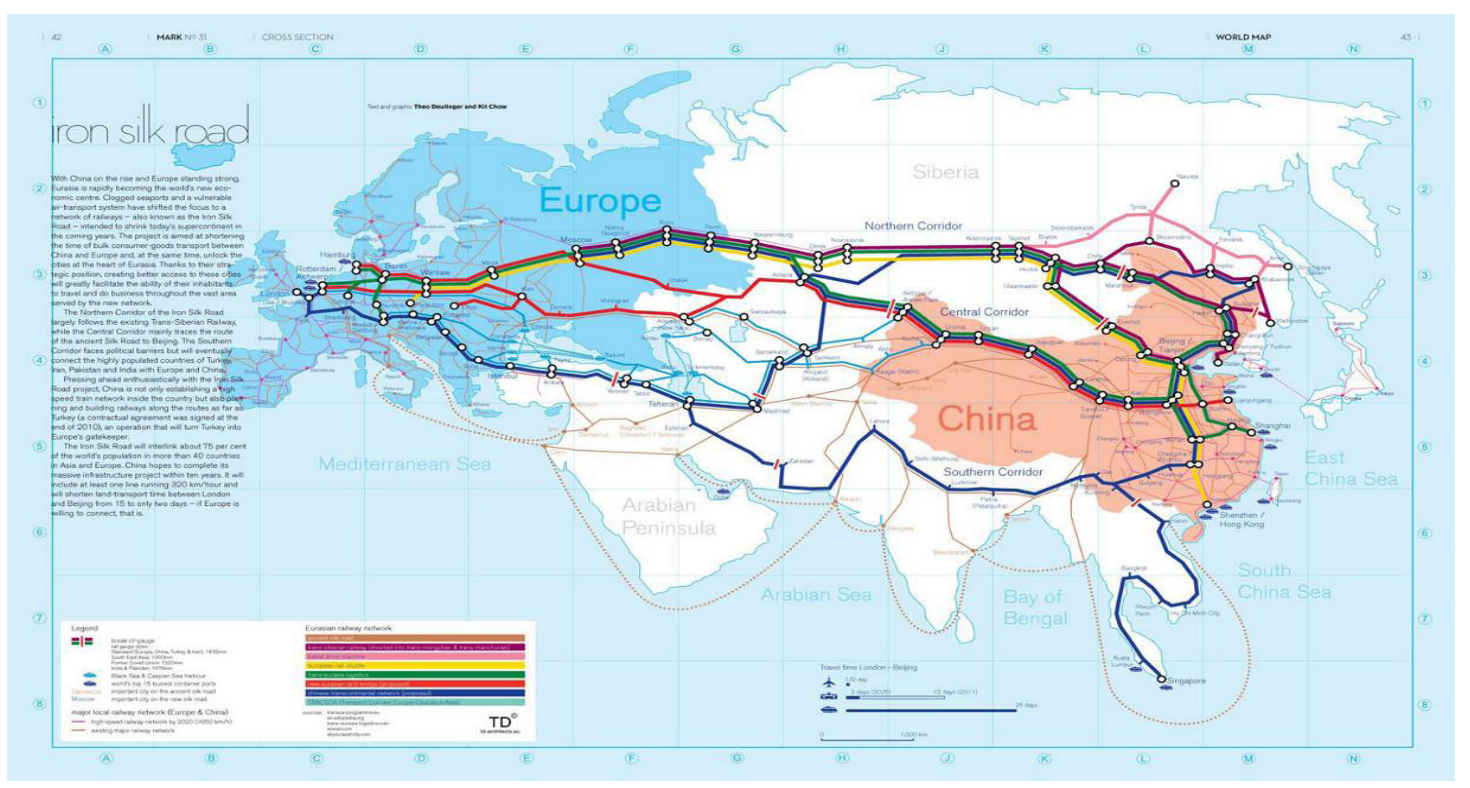

Peta Jalur Sutra Modern darat dan laut (sumber: chinadiscovery.com, 2020) 


\section{Kehadiran Tiongkok di Timur Tengah Melalui Skema BRI}

Tiongkok datang ke Timur Tengah tak hanya membawa kepentingan energi. Dunia tahu bahwa minyak bukan energi terbarukan sehingga perlu ada inovasi lain manakala kondisi minyak mulai menipis. Tiongkok menawarkan skema kerjasama dengan negara-negara di dunia, termasuk di kawasan Timur Tengah, dengan agenda the Belt and Road initiative (BRI). BRI dibagi menjadi dua bagian penting: Silk Road Economic Belt (SREB) dan Maritime Silk Road (MSR). Keduanya bekas Jalur Sutra yang ingin dihidupkan kembali dengan wajah modernitas dan konektivitas yang lebih cepat. Ada banyak negara yang tadinya menolak akhirnya bergabung setelah negara tetangga ikut terlibat. Misalnya, Arab Saudi yang tadinya menolak, namun akhirnya tertarik karena Iran, saingan berat di kawasan Timur Tengah, bergabung dalam skema BRI (Sarwar, 2017: 15-16).

BRI Tiongkok mulai dikenalkan oleh presiden Tiongkok, Xi Jinping, ketika berkunjung ke Kazakhstan pada 2013. Tiongkok menawarkan investasi besarbesaran, pinjaman dan bantuan sekaligus untuk memuluskan agenda politik luar negerinya. Dana-dana tersebut digunakan untuk berbagai proyek infrastruktur seperti: pembangunan jalan, rute kereta api, pipa energi, jaringan listrik, pelabuhan, dan bandara. Tak hanya keuntungan ekonomi, Tiongkok juga mendapatkan keuntungan politik. Citranya di mata dunia, termasuk Timur Tengah, kian meningkat dan hubungannya dengan negara-negara di Timur Tengah semakin dekat (Yu, 2018: 137-138).

Tak tanggung-tanggung, Tiongkok menyediakan suntikan dana sebesar 40 triliun Dolar AS khusus untuk BRI kerjasama ekonomi dan 100 triliun Dolar AS melalui Asia Infrastructure Investment Bank (AIIB), dengan Arab Saudi, UEA dan Iran sebagai peraih tertinggi investasi tersebut di Timur Tengah (Kamel, 2018: 77-78). Infrastruktur ini tidak hanya berkaitan dengan suplai energi, namun juga konektivitas industri kreatif dan pariwisata yang menjadi langkah strategis Timur Tengah agar negaranegara kawasan tidak bergantung pada minyak.

Langkah ini bisa dilihat dari industri-industri kreatif dan priwisata yang mulai ditingkatkan di berbagai negara Timur Tengah. Jumlah wisatawan yang masuk akan meningkatkan perekonomian mikro maupun mikro. Di Timur Tengah, most visited country 2019 diraih oleh Turki dengan total jumlah turis asing mencapai 46 juta, jumlah yang menempatkannya di peringkat ke-6 dunia. Jumlah ini naik secara signifikan dari posisi ke-8 dunia pada 2017. Peringkat lainnya di Timur Tengah disusul oleh Arab Saudi, Bahrain, dan Uni Emirat Arab (Nag, 2019). Sementara most visited city 
2019, Dubai UEA meraih posisi ke-4 di dunia dengan jumlah wisman 15 juta, disusul Istanbul dan Antalya di Turki dengan posisi ke-8 dan ke-10, lalu posisi di bawahnya ditempati Mekkah, Arab Saudi (Millington, 2019).

Tak hanya di bidang pariwisata, iklim investasi ilmu pengetahuan dan teknologi juga semakin digenjot oleh beberapa negara Timur Tengah. UEA membentuk "UAE Strategy for Artificial Intelligence" yang menjadi proyek pertama dari skema "UAE Centennial Plan 2071". Proyek ini dicanangkan untuk memudahkan pelayanan publik, ekonomi warga, dan industri hiburan dalam jangkauan digital (Suwaidi, 2018: 90-91). Arab Saudi juga mulai mengizinkan wanita mengemudi mobil dan bekerja, karena di antara negara-negara G20, negara Arab itu meraih angka pengangguran wanita terdidik paling tinggi. Dibentuknya "Princess Nourah bint Abdulrahman University" (PNU) sebagai universitas khusus wanita terbesar di dunia, memungkinkan wanita mendapatkan pelatihan vokasi di bidang bisnis dan teknologi sehingga bisa mengurangi angka pengangguran wanita terdidik (Smith, 2020).

Baik industri kreatif, pariwisata maupun investasi pendidikan dan teknologi tidak bisa dilepaskan begitu saja dari eksistensi Jalur Sutra. Kehadiran Tiongkok di Timur Tengah melalui BRI membuka kemesraan Tiongkok dengan beberapa negara di kasawan itu. Ini berbeda dengan beberapa tahun silam, dimana ideologi Komunisme Tiongkok ditakuti di Timur Tengah. Beberapa negara di sana pun akhirnya memilih lebih dekat dengan Barat. Tiongkok yang sekarang bukanlah negara komunis murni seperti dulu. Negara ini mulai dikenal sebagai one country two systems dimana di dalam negerinya menerapkan Komunisme, namun di luar negeri, mereka menerapkan Kapitalismeme di pasar global. BRI yang dibawa Tiongkok ini merupakan wujud dari kapitalisme pasar Tiongkok (Ehteshami, 2018: 192-193).

Tak seperti AS dan Barat yang selain membawa kapitalisme dan militer ke Timur Tengah dengan intervensi urusan dalam negeri negara-negara kawasan seperti: Irak, Suriah atau Yaman, Tiongkok cenderung menghindari konflik di Timur Tengah dengan prinsip non-intervensi. Kehadirannya di Timur Tengah murni menggunakan pendekatan ekonomi. Pendekatan ini membuat Tiongkok dapat diterima baik di Israel ataupun di Palestina. Tiongkok juga mudah diterima di Irak dan Suriah, mudah diterima baik di Arab Saudi maupun Iran. Menurut survei dari Pew Research Center, lebih dari setengah penduduk Palestina memandang positif kehadiran Tiongkok ketimbang AS. Mereka juga berpendapat bahwa posisi percaturan ekonomi AS di Timur Tengah sudah digeser oleh Tiongkok (Burton, 2018: 162-163). 
Tiongkok mendukung pemerintahan yang sah berkuasa di Timur Tengah, karena mereka lebih fokus pada negara (pemerintah), sementara AS berusaha juga menjaga hubungan dengan semua elemen, termasuk oposisi. Pendekatan Tiongkok yang murni bisnis ini memungkinkan dirinya dekat dengan konglomerat atau pengusaha swasta yang dekat dengan pemerintah. Tiongkok membatasi diri untuk berhubungan dengan oposisi dan permasalahan di Timur Tengah. Namun kondisi ini kadang mempersulit posisi Tiongkok jika suatu saat kekuatan pemberontak dan kubu oposisi menjadi penguasa yang sah menggantikan rezim yang berkuasa sebelumnya (Dorsey, 2019: 193-194).

Anggapan tersebut bisa benar, bisa juga salah, apalagi melihat power Tiongkok yang semakin besar di dunia, termasuk di Timur Tengah, berkat suntikan dana BRI. Meskipun membatasi diri dari konflik di Timur Tengah, ambisi Tiongkok di Timur Tengah tak lain adalah menjadi hegemoni dunia dengan paham neokolonialismenya, tak jauh berbeda dengan rivalnya, AS dan Barat. Terutama jika Jalur Sutra modern selesai dibangun, maka jalur perdagangan dan perputaran ekonomi dunia akan lebih dekat. Jalur itu nantinya akan terbuka mulai dari Laut China Selatan (melewati Asia Timur, Asia Tenggara, Asia Selatan, Laut Arab) sampai Eropa, dari Afrika Utara hingga Kutub Utara. Tiongkok pun menjadi negara yang paling diuntungkan, karena barang produksinya bisa dirasakan sampai ujung dunia (Mayer \& Zhang, 2020: 1-3).

\section{Balancing Power Iran dan Arab Saudi dan Masa Depan RSCs Timur Tengah dengan Skema BRI Tiongkok}

Di Timur Tengah, dua kekuatan besar regional selalu disematkan kepada Iran dan Arab Saudi. Kedua negara juga dianggap oleh sebagian pihak mewakili aliran dalam Islam, Sunni dan Syiah. Perbedaan kedua aliran ini ditengarai memicu konflik kawasan, meskipun ada kepentingan politik dan ekonomi yang sangat kuat di balik konflik atas nama aliran agama tersebut. Baik Iran dan Arab Saudi memiliki wilayah teritorial terbesar di antara negara-negara Timur Tengah. Kedua negara itu memiliki peran dan pengaruh kuat atas kondisi Timur Tengah saat ini karena keterlibatan mereka.

Kedekatan Arab Saudi dengan AS bertolak belakang dengan Iran yang sangat anti terhadap AS. Meski begitu, kedua negara kompak dalam menerima suntikan dana BRI dari Tiongkok. Perekonomian Arab Saudi termasuk yang terbesar di Timur Tengah kemudian disusul oleh Iran. Kedua negara mempunyai cadangan minyak terbesar di kawasan. Kondisi ini sangat menguntungkan Tiongkok yang ekonominya 
bergantung pada minyak mentah dan gas. Terutama jika melihat kondisi Iran yang mendapat sanksi dari dunia Barat, Tiongkok seolah bisa membaca situasi ini sehingga Iran menjalin kedekatannya dengan Tiongkok untuk menyuplai kebutuhannya pada minyak mentah (Kamel, 2018: 85).

\begin{tabular}{|c|c|c|c|c|c|}
\hline Country ${ }^{*}$ & $\begin{array}{c}\text { AIIB } \\
\text { membership }\end{array}$ & $\begin{array}{l}\text { MOU } \\
\text { on BRI }\end{array}$ & $\begin{array}{l}\text { Partnership level } \\
\text { with China }\end{array}$ & $\begin{array}{c}\text { Total } \\
\text { Trade with } \\
\text { China } \\
\text { (US\$B) }^{*}\end{array}$ & $\begin{array}{c}\text { Major BRI related } \\
\text { project }\end{array}$ \\
\hline Iran & $\sqrt{ }$ & $\sqrt{ }$ & $\begin{array}{l}\text { Comprehensive } \\
\text { Strategic Partnership } \\
\text { (2016) }\end{array}$ & 33.8 & $\begin{array}{l}\text { Oil refineries and } \\
\text { railway projects }\end{array}$ \\
\hline KSA & $\sqrt{ }$ & $\sqrt{ }$ & $\begin{array}{l}\text { Comprehensive } \\
\text { Strategic Partnership } \\
\text { (2016) }\end{array}$ & 51.6 & $\begin{array}{l}\text { Investments in } \\
\text { Energy sector \& } \\
\text { trade cooperation }\end{array}$ \\
\hline Egypt & $\sqrt{ }$ & $\sqrt{ }$ & $\begin{array}{l}\text { Comprehensive } \\
\text { Strategic Partnership } \\
\text { (2014) }\end{array}$ & 12.8 & $\begin{array}{l}\text { China-Egypt Suez } \\
\text { Economic and Trade } \\
\text { Cooperation Zone }\end{array}$ \\
\hline UAE & $\sqrt{ }$ & $\sqrt{ }$ & Strategic Partnership & 48.5 & $\begin{array}{l}\text { Financial and } \\
\text { Commercial }\end{array}$ \\
\hline Israel & $\sqrt{ }$ & & & 11.4 & $\begin{array}{l}\text { Red-Med Railway } \\
\text { project }\end{array}$ \\
\hline Qatar & $\sqrt{ }$ & & Strategic Partnership & 6.8 & $\begin{array}{l}\text { Financial and } \\
\text { Commercial }\end{array}$ \\
\hline Bahrain & & & - & 1.1 & $\begin{array}{l}\text { Trade and invest- } \\
\text { ment }\end{array}$ \\
\hline Kuwait & $\sqrt{ }$ & $\sqrt{ }$ & & 11.2 & Silk City \\
\hline Jordan & $\sqrt{ }$ & & $\begin{array}{l}\text { Strategic Partnership } \\
\text { (2015) }\end{array}$ & 3.7 & $\begin{array}{l}\text { Sino-Jordanian } \\
\text { University }\end{array}$ \\
\hline Lebanon & & & & 2.3 & \\
\hline Djibouti & & & $\begin{array}{l}\text { Security and Defence } \\
\text { Strategic Partnership } \\
\text { (2014) }\end{array}$ & 1.9 & Free Trade Zone \\
\hline Iraq & $\sqrt{ }$ & $\sqrt{ }$ & $\begin{array}{l}\text { Strategic Partnership } \\
\text { (2015) }\end{array}$ & 20.5 & $\begin{array}{l}\text { Trade and } \\
\text { Infrastructure }\end{array}$ \\
\hline Syria & & & & 1 & - \\
\hline Oman & $\sqrt{ }$ & $\sqrt{ }$ & Strategic Partnership & 17.1 & $\begin{array}{l}\text { Industrial zone in } \\
\text { Duqm }\end{array}$ \\
\hline
\end{tabular}

Hubungan Tiongkok dengan 14 negara di Timur Tengah dalam skema BRI (sumber: National Bureau of Statistics of China)

Dari data di atas, terlihat bahwa baik Iran maupun Arab Saudi sama-sama menerima suntikan dana dari Tiongkok. Meski proyeknya berbeda satu sama lain, namun semuanya berhubungan erat dengan Jalur Sutra melalui skema BRITiongkok. Iran menerima 33.9 miliar Dolar untuk penyulingan minyak dan jalur kereta, 
sedangkan Arab Saudi menerima 51.6 miliar Dolar untuk investasi di bidang energi dan kerjasama perdagangan. Kedua negara sama-sama menandatangani MoU BRI dan turut serta dalam Asia Infrastructure Investment Bank (AIIB). Itu artinya mereka sama-sama menerima pembangunan infrastruktur di negara mereka yang luas.

BRI ini bukan program jangka pendek yang segera selesai setelah suntikan dana diberikan. Skema ini merupakan program jangka panjang yang, meskipun minyak telah habis, jalur perdagangan yang dibawa Tiongkok masih tetap eksis mengantarkan barang-barang dari Tiongkok ke berbagai negara Timur Tengah. Apalagi semua jalur, baik darat, laut dan udara di Timur Tengah, semakin diperbaiki dan saling terkoneksi satu dengan lainnya. Ini memungkinkan Tiongkok untuk tetap menghegemoni ekonomi Timur Tengah di masa yang akan datang.

Dalam menjalin relasi dengan negara-negara di Timur Tengah, Tiongkok memilih untuk tidak terlibat langsung dalam konflik. Antara lain bisa dilihat dari hubungannya yang, selain menjalin kerjasama dengan Israel, juga mengikat kerjasama dengan Palestina. Dalam kasus Israel, Tiongkok menjalin hubungan di bidang teknologi dan ekonomi. Bila dilihat sejarahnya, pada saat Israel baru berdiri sekitar 1950-an, Tiongkok berdiri di belakang negara-negara Arab yang menentang Israel. Israel pun menunda jalinan hubungan dengan Tiongkok. Kondisi ini tidak berlangsung sama setelah Israel dan Tiongkok mulai memperbaiki hubungan pada 1992. Pada tahun itu, Israel merupakan negara pertama di Timur Tengah yang mendukung kebijakan "Beijing's One China" (Ehteshami, 2018: 120). Di saat yang sama, Tiongkok juga memberikan dukungan kepada Palestina, yang antara lain diapresiasi oleh PM Palestina, Perdana Menteri Palestina, Mohammad Ishtaye. Dalam perayaan merayakan ulang tahun ke 70 pendirian RRT September 2019, Ishtaye memuji Tiongkok karena selalu menjadi "pilar pendukung" bagi Otoritas Palestina dan perjuangan Palestina untuk mencapai kenegaraan dan kemerdekaan (xinhua.net, 2019).

Jika dilihat melalui perspektif Regional Security Complex, Tiongkok telah memosisikan diri sebagai sahabat semua negara Timur Tengah, termasuk Arab Saudi dan Iran; atau Israel dan Palestina. Namun, kondisi ini di saat-saat tertentu dapat berubah seiring eskalasi politik global. Misalnya, dalam kasus Iran dan Suriah, Tiongkok berposisi sebagai penyeimbang kekuatan (balance of power) dengan menolak intervensi militer AS Suriah. Tiongkok berkali-kali menggunakan power-nya untuk memveto resolusi yang menekan Iran atau Suriah. Dalam kasus embargo AS terhadap Iran, dimana negara-negara dunia, seperti Eropa atau Jepang mundur dari kerja sama dengan Iran untuk mematuhi embargo AS, Tiongkokjustru memanfaatkan kondisi ini sebagai peluang bisnis, mulai dari migas hingga infrastruktur. Kemauan 
Tiongkok untuk tetap menjalin kerja sama bisnis dengan Iran merupakan bentuk soft power Tiongkok untuk memperkuat hegemoninya di kawasan (Yulianti dan Affandi, 2018) dan sisi lain, menjadi penyeimbang kekuatan AS di kawasan. Kedekatan Tiongkok dengan Iran kemudian direspon oleh AS dengan menjalin hubungan yang lebih erat dengan Arab Saudi.

\section{Simpulan}

Pasca Perang Dingin, dunia bergerak ke arah kemajuan ekonomi dan teknologi sehingga kekuatan militer tidak lagi menjadi kunci utama dalam penguasaan dunia. Aliansi yang terjalin di antara negara-negara tidak lagi sebatas militer, melainkan juga saling membentuk aliansi ekonomi. Negara yang ekonominya kuat berkemungkinan menjadi hegemoni global dan berani menantang superioritas AS. Kondisi inilah yang terjadi dewasa ini, ketika Tiongkok muncul sebagai raksasa ekonomi global yang perlahan-lahan menggeser posisi AS sebagai hegemoni global.

Dalam upayanya untuk memperluas penguasaan ekonomi global, Tiongkok berupaya menghidupkan kembali Jalur Sutra dalam skema Belt and Road Initiative (BRI). Proyek besar ini memiliki visi jangka panjang, dimana setelah minyak mulai habis, ekonomi kreatif, pariwisata, pendidikan, transfer teknologi dan perdagangan akan memainkan peran penting. Di sinilah peran BRI, yaitu untuk memudahkan mobilisasi sendi-sendi kehidupan dan perekonomian di Jalur Sutra, termasuk Timur Tengah.

Dalam rangka mewujudkan skema BRI, Tiongkok menjalin kembali hubungan yang lebih erat dengan negara-negara Timur Tengah. Jalur Sutra Modern diwarnai dengan kemegahan infrastruktur, mulai dari pelabuhan, stasiun, jalan raya ataupun bandara. Semua jalur terkoneksi lebih cepat untuk memudahkan perpindahan barang produksi. Sebagai dampaknya, di satu sisi terjadi pembangunan pesat di negara-negara Timur Tengah dengan investor dari Tiongkok, di saat yang sama, barang-barang produksi dari Tiongkok pun menyebar luas ke seluruh penjuru Timur Tengah.

Kondisi ini menunjukkan bahwa Tiongkok menjadi penyeimbang kekuatan baru di Timur Tengah di hadapan power AS yang semula mendominasi kawasan ini. Salah satu penyebab kesuksesan Tiongkok ini adalah prinsip non-intervensinya, dimana Tiongkok memilih berteman dengan semua negara, termasuk dengan negara yang saling berkonflik. Misalnya, Tiongkok menjalin kerja sama erat dengan Iran dan Arab Saudi, atau dengan Israel dan Palestina. Dalam perspektif Regional Security Complex, 
Tiongkok berperan sebagai sahabat semua negara Timur Tengah. Namun, kondisi ini akan berubah seiring eskalasi politik global, apalagi bila AS membangun aliansi untuk menghambat kehadiran Tiongkok di kawasan. Dalam kondisi ini, bisa saja negara-negara yang semula menjalin kerja sama dengan Tiongkok akan membelot. Dalam kasus Iran versus Arab Saudi, misalnya, Tiongkok memilih mengabaikan embargo dari AS dengan tetap menjalin kerja sama bisnis dengan Iran; sehingga AS kemudian berupaya melakukan pengimbangan dengan mendekati Arab Saudi.

\section{Daftar Pustaka}

Al-Rawashdeh, M. S., \& Al-Qatatsheh, M. H. (2017). China's strategy in the Middle East (The Silk Road Project). IOSR Journal Of Humanities And Social Science, 22(1), 3751.

Barry Buzan, O. W. (2003). Regions and Powers the Structure of International Security. Cambridge: Cambridge University Press.

Brenner, W. J. (2007). The Forest and the King of Beasts: Hierarchy and Opposition in Ancient India (c. 600-232 BCE). Dalam: Stuart, William, Richard, Arthur, Victoria, \& Daniel, The Balance of Power in Wolrd History. New York: Palgrave MacMillan., 99-121.

Burton, G. (2018). How do Palestinians Perceive China's Rise?. Dalam: Andrew, Sara, Yitzhak, \& A. e. all, China's Presence in the Middle East. New York: Routledge., 158173.

Dorsey, J. M. (2019). China and the Middle East. Switzerland: Palgrave Macmillan.

E.Long, D., \& Reich, B. (2002). The Government and Politics of The Middle East and North Africa. Colorado: Westview Press.

Eckstein, A. M. (2007). Intra-Greek Balancing, the Mediterranean Crisis of c. 201-200 $B C E$, and the Rise of Rome. Dalam: Stuart, William, Richard, Arthur, Victoria, \& Daniel, The Balance of Power in World History. New York: Palgrave MacMillan., 7198.

Ehteshami, A. (2018). The One Belt, One Road in China's grand strategy. Dalam: Andrew, Sara, Yitzhak, \& A. e. all, China's Presence in the Middle East. New York: Routledge., 192-209. 
Farah, N. (2014). Perkembangan Ekonomi dan Administrasi pada Masa Bani Umayyah dan Bani Abbasiyah. Al Amwal, 6(2), 37-46.

Forêt, P., \& Kaplony, A. (2008). Silk Road Studies. Dalam: N. Zufferey, A. Kaplony, \& P. F. all, The Journey of Maps and Images on the Silk Road. Leiden: Koninklijke Brill NV., $1-9$.

Freely, J. (2019). Istanbul: The Imperial City (terjemahan). Tangerang Selatan: Pustaka Alvabet.

Hanifah. (2017). Peran Sultan Sulaiman Al Qanuni dalam Membangun Kejayaan Kesultanan Turki Utsmani pada Abad Ke-16. Tamaddun, 98-115.

Ho, W. Y. (2013). Islam and China's Hongkong. New York: Routledge.

Hui, V. T.-b. (2007). The Triumph of Domination in the Ancient Chinese System. Dalam: Stuart, William, Richard, Arthur, Victoria, \& Daniel, The Balance of Power in World History. New York: Palgrave MacMillan., 122-147.

Julien Barnes-Dacey, E. G. (2019). The Middle East's New Battle Lines. [online] ECFR. Dalam: https://www.ecfr.eu/mena/battle_lines/ [Diakses 25 Mei 2020].

Kamel, M. S. (2018). China's Belt and Road Initiative: Implications for the Middle East. Cambridge Review of International Affairs, 76-95.

Kaufman, S. J., \& Wohlforth, W. C. (2007). Balancing and Balancing Failure in Biblical Times: Assyria and the Ancient Middle Eastern System, 900-600 BCE. Dalam: Stuart, William, Richard, Arthur, Victoria, \& Daniel, The Balance of Power in World History. New York: Palgrave MacMillan., 22-46.

Levinson, D. (1994). Encyclopedia of World Cultures Volume IX Africa and Middle East. New York: G.K. Hall \& Company.

Little, R. (2007). The Balance of Power in International Relations: Metaphors, Myths and Models. Cambridge: Cambridge University Press.

Little, R. (2007). The Greek City-States in the Fifth Century BCE: Persia and the Balance of Power. Dalam: Stuart, William, Richard, Arthur, Victoria, \& Daniel, The Balance of Power in Wolrd History. New York: Palgrave MacMillan., 47-70.

Liu, X. (2010). The Silk Road in World History. New York: Oxford University Press. 
Mayer, M., \& Zhang, X. (2020). Theorizing China-World Integration: Sociospatial Reconfigurations and the Modern Silk Roads. Review of International Political Economy, 1-30. doi:https://doi.org/10.1080/09692290.2020.1741424

Millington, A. (2019). The 19 most visited cities around the world in 2019. [online] Business Insider. Dalam: https://www.businessinsider.sg/most-visited-citiesaround-the-world-ranked-2019-9?r=US\&IR=T [Diakses 20 Mei 2020].

Murad, M. (2007). Utsman bin Affan. Jakarta: Zaman.

Nag, O. S. (2019). The World's Most Visited Countries. [online] World Atlas. Dalam: https://www.worldatlas.com/articles/10-most-visited-countries-in-the-world. html [Diakses 21 Mei 2020].

Onsman, A. (2011). It is better to light a candle than to ban the darkness: government led academic development in Saudi Arabian Universities. Springer Science and Business Media, 519-532.

Partowidagdo, W. (2014). Sejarah Penemuan Minyak di Dunia. [online] Migas ESDM. Dalam: $\quad$ https://migas.esdm.go.id/post/read/Sejarah-Penemuan-Minyak-diDunia [Diakses 26 Mei 2020].

Pratama, A. N. (2018). Berusia lebih dari 140 Tahun, Ini 6 Fakta Menarik Terusan Suez. Kompas, [online]. Dalam: https://internasional.kompas.com/ $\mathrm{read} / 2018 / 11 / 17 / 13212381 /$ berusia-lebih-dari-140-tahun-ini-6-fakta-menarikterusan-suez?page=2 [Diakses 20 Mei 2020].

R. Brawley, M. (2004). The Political Economy of Balance of Power Theory. Dalam: J. Levy, D. Lemke, M. R.Brawley, C. Layne, \& J. J. all, Balance of Power: Theory and Practice in The 21st Century. Stanford: Stanford University Press., 76-102.

Sarwar, L. (2017). The Old Silk Road and the New Silk Road: An Analysis of the Changed Discourse. The Journal of Central Asian Studies, 24, 13-22.

Sheehan, M. (2000). The Balance of Power: History and Theory. New York: Routledge.

Sihbudi, R. (2007). Menyandera Timur Tengah. Jakarta: Mizan.

Smith, M. (2020). The Middle East's other revolution: Tech trends from Morocco to Oman. [online] Wired. Dalam: https://wired.me/technology/middle-east-technologytrends-from-morocco-to-oman/ [Diakses 26 Mei 2020]. 
Suwaidi, J. S. (2018). UAE Society in The Twenty-first Century: Issues and Challenges in a Changing World. Abu Dhabi: UEA.

T.V. Paul. (2004). The Enduring Axioms of Balance of Power Theory and Their Contemporary Relevance. Dalam: Jack, Douglas, Mark, \& J. dkk, Balance of Power: Theory and Practice in The 21st Century. California: Stanford University Press., 1-28.

Tobing, S. (2020). Naik-Turun Harga Minyak Setiap Terjadi Konflik di Timur Tengah. Kata Data, [online]. Dalam: https://katadata.co.id/berita/2020/01/09/naik-turunharga-minyak-setiap-terjadi-konflik-di-timur-tengah [Diakses 25 Mei 2020].

Ulum, F. (2015). Sejarah Pemikiran Ekonomi Islam. Surabaya : IAIN Sunan Ampel \& IDB.

Yang, S.-y. (2013). Power Transition, Balance of Power, and the Rise of China: A Theoretical Reflection about Rising Great Powers. The China Review, 13(2), 35-66.

Yu, W. (2018). Economic and Cultural Interactions between Israel and China. Dalam: Andrew, Sara, Yitzhak, \& A. e. all, China's Presence in the Middle East. New York: Routledge., 137-157.

Yulianti, D. dan Affandi, RMTN. (2018). Strategi Soft Power Dalam Ekspansi Ekonomi China Di Timur Tengah: Studi Kasus Kerjasama China-Iran. Mandala, 1(2), 247265.

Xinhua.net. (2019). Palestinian PM lauds China's unwavering support to Palestinian cause. [online]. Dalam: http://www.xinhuanet.com/english/201909/24/c_138419182_2.htm [Diakses 25 Mei 2020]. 